\title{
Understanding the needs and challenges of a Black community in South Africa
}

\author{
Venicia McGhie and Marion Keim
}

\begin{abstract}
This article reports on a study conducted with an unemployed group of community members residing in the Gugulethu Township in South Africa. The study aimed to gain an in-depth understanding of their needs and challenges, and what they thought could be done to assist and empower them so that they could improve their lives. Their basic human needs were violated during apartheid and as a consequence, they are still battling poverty today. We offer suggestions on how Black communities in South Africa could be supported and empowered in order to become employable and self-reliant.
\end{abstract}

\section{Introduction}

More than twenty years into democracy in South Africa the majority of the South African Black population (African and coloured) is still battling with poverty, high unemployment, disadvantaged schooling, and a lack of financial resources as a result of apartheid's ideology prior to 1994 (Organization for Economic Co-operation and Development 2008; Kros 2010; Liebenberg 2014). Currently, the unemployment rate stands, at its most expanded estimate, at 35\% (Statistics South Africa 2015). Many African and coloured communities are therefore dependent on the government's social grants as their only source of income. According to the Deputy CEO of the Institute of Race Relations, the country's reliance on welfare is unsustainable as there are more people on welfare than people who work and job creation is vital (South African Institute of Race Relations 2015).

Since its inception in 1994, the new democratic government has attempted to transform South Africa in order to empower and uplift the Black population, and eradicate poverty and unemployment. The government introduced the Employment Equity Act, the Reconstruction and Development Program, and the Black Economic Empowerment Program (Department of Trade and Industry 2015). However, only a minority of the Black elite has benefited from these initiatives and the marginalised and improvised majority remained powerless (Moodley 1995; Tight 2003). The South African Institute of Race Relations proposes one solution to the challenges that the government faces in its 85th Annual Report, which states that "The inputs needed to empower the disadvantaged include decent schooling, opportunities for tertiary training on the sound foundation thus laid, a realistic chance of jobs and income, and 
the entrepreneurial skills and other inputs needed for success in business" (South African Institute of Race Relations 2015, 17).

The democratic government still faces a mammoth task, due to the inheritance of one of the most unequal societies in the world (Ministry of Finance 2001). The Ministry of Finance (2001) explains that South Africa has a two-tiered economy - one developed, largely White, and similar to other developed countries; and one underdeveloped, largely Black, and with only the most basic infrastructure; and an estimated 60\% Black population that is poverty stricken.

It is against this background that this article reports on a study conducted in 2013 with an unemployed group of 27 men and women residing in the Gugulethu Township on the Cape Flats in the Western Cape Province in South Africa. The study's aim was to gain an in-depth understanding of the needs and challenges of unemployed community residents, and what they thought could be done to assist and empower them so that they could improve their lives. The study objective was to arrive at a holistic approach that could address the health, nutritional, and well-being needs of the group in order to overcome apartheid's legacy and enable them to become employable and sustained. The main question the study attempted to answer was: how could this group of unemployed residents of Gugulethu become empowered and selfreliant? Three sub-questions guided the analysis and discussion:

1. What were the most pressing needs, challenges, and aspirations of the group?

2. How could their needs be met and the challenges be overcome?

3. What was the educational value that the women gained from attending the educational course?

In order to avoid ambiguity, the concept "needs" refer to basic human needs which include nutrition and basic medical care, water and sanitation, shelter, and personal safety (Porter, Stern, and Green 2015). The concept "challenges" is used to refer to difficulties Gugulethu residents experienced due to their socio-economic and historical backgrounds, as outlined in the next section.

\section{The case}

Gugulethu is one of many Black townships on the Cape Flats in the Western Cape in South Africa. The context and living conditions of Black communities are similar across the nine provinces of South Africa as a direct consequence of apartheid's ideology. A census conducted in 2011 by the City of Cape Town revealed that Gugulethu's population of 98,468 was $99 \%$ African Black, with the remaining $1 \%$ a mixture of other cultural groups. The census reflected that $31.5 \%$ of adults aged 20 and older had completed their secondary schooling (Grade 12), while $47 \%$ did not complete their secondary schooling, and the remaining $21.5 \%$ only completed primary schooling, and some did not attend school at all. The census further reflected that $5.7 \%$ of the adults who completed secondary schooling continued to higher education and hold a degree or diploma. 
According to the labour force indicators used in the census, of the 68,274 of the population who were at a working age (aged 15 to 64 ) in 2011, 44,382 (65\%) had some form of employment, while 17,682 (26\%) were unemployed. The majority of the employed population (28.9\%) lived on a monthly income of between R1.0o and $\mathrm{R} 1,600 ; 23.2 \%$ had a monthly income of R1,601-R3,200; $15.3 \%$ had a monthly income of R3,201-R6,400; $8.5 \%$ had an income of R6,401-R12,800; and only $4.5 \%$ had a monthly income of R12,801 and more. In 2013, 52\% of the Black Africans lived in a formal dwelling (proper house), 6.3\% lived in informal dwellings, in the backyards of someone else, and $41 \%$ lived in informal dwellings on an open unconfined piece of land (City of Cape Town 2013).

The group of 27 (20 males and seven females) respondents formed part of the $26 \%$ of the working age but unemployed population of Gugulethu. Three of the women had completed Grade 12, two left school in Grade 9 and two only completed Grade 4. The majority of the men had only completed Grade 8 . These men and women were some of the community members who came to the daily soup kitchen provided by a non-profit organisation called Women for Peace, based in the Gugulethu Township. The organisation provides a free meal to unemployed community members from Mondays to Fridays. The group indicated that they wanted to better themselves educationally and acquire skills in order to find employment and improve their lives.

We interacted closely with Women for Peace as part of our university's community engagement responsibility. The organisation contacted and requested us to work with the group and to conduct a study to investigate what the groups' needs and challenges were. The study was subsequently conducted in 2013. To this end, their selection was a convenient sampling method.

\section{Analytic framework}

The study focused on a specific group of community members' needs and challenges. As such, it was about their historical and socio-economic backgrounds within a marginalised and disempowered context. For this reason, Vygotsky's (1979, 1994) Social Cultural Theory and Max-Neef's $(1989,1992)$ Human Scale Development Theory were applied as analytic framework. Vygotsky's Social Cultural Theory provided an understanding of why the majority of the Black population in South Africa are in their current situation; while Max-Neef's Human Scale Development Theory was suited to analyse and evaluate the groups' human development needs and satisfiers within their lived realities of unemployment and poverty.

Vygotsky argues that the environment in which humans operate is the source of the development of their personalities and characteristics (Vygotsky 1994, 352). He explains:

"As an individual only exists as a social being, as a member of some social group within whose context he follows the road of his historical development, the composition of his personality and the structure of his behaviour turn out to be a quantity which is dependent on social evolution and whose main aspects are determined by the latter." (Vygotsky 1994, 175-176) 
To this extent, he argues that "human beings actively realise and change themselves in the varied contexts of culture and history" (Vygotsky 1979, 131).

Vygotsky elucidates that the development of human beings gave rise to the underpinnings of capitalism: the division between intellectual and physical labour, the separation between town and country, the exploitation of child and female labour, poverty and the unequal development of human beings' potential as one extreme thereof. Vygotsky concludes: "As a result of capitalism, the development of material production simultaneously brought with it the progressive division of labour and the constantly growing distorted development of the human potential" (Vygotsky 1994, 178). Vygotsky's theory of the consequences of capitalism, therefore, accounts for the differences in socio-economic and political power, the huge disparities in the labour force of a country, and the spread of wealth and resources. Vygotsky's social cultural theory is framed within a social justice and social construction paradigm.

As the statistics presented in the introduction show, most of the population in Gugulethu had limited education due to South Africa's apartheid history, where one race was regarded and treated as superior to others in all spheres of life. Consequently, a large number of the people in Gugulethu are still today uneducated and unskilled, forming part of the working class and poorer communities of South Africa. South Africa is therefore an example of how the division of human beings into different social class categories have negatively impacted its citizens.

Max-Neef's Human Scale Development Theory concentrates on and is sustained by the satisfaction of fundamental human needs and the generation of growing levels of selfreliance (Max-Neef 1992, 197). His theory acknowledges that, due to the common human nature, humans need to satisfy some fundamental needs - common to everyone - in order to sustain a rich and meaningful life. According to Max-Neef, "Human Scale Development assumes a direct participatory democracy" (Max-Neef 1989, 13). He argues that Human Scale Development embodies the diversity, as well as the autonomy of the spaces in which humans function, and that must be respected.

Max-Neef advocates the classification of human needs according to many criteria, but considers two categories, namely the existential and axiological, as most important. These two demonstrate, on the one hand, the interaction of the needs of being, having, doing, and interacting, and, on the other hand, the needs of subsistence, protection, affection, understanding, participation, creation, leisure, identity, and freedom (MaxNeef 1992; Cruz, Stahel, and Max-Neef 2009). From the proposed classi- fication, it follows that food and shelter, for instance, must not be seen as needs, but as satisfiers of the fundamental need for subsistence. In much the same way, education (either formal or informal), study, investigation, early stimulation and meditation are satisfiers of the need for understanding. However, there is no one-to-one correspondence between needs and satisfiers. A satisfier may con- tribute simultaneously to the satisfaction of different needs, or, conversely, a need may require various satisfiers in order to be met. Not even these relations are fixed, however, as they may vary according to time, place and circumstance (ibid.).

\section{http://repository.uwc.ac.za}


On the basis of the establishment of the difference between the concepts of needs and satisfiers, Max-Neef identifies two postulates: first, fundamental human needs are finite, few, and classifiable; and, second, fundamental human needs are the same in all cultures and in all historical periods (Max-Neef 1992). What changes, both over time and through cultures, is the way or the means by which the needs are satisfied. Each economic, social, and political system adopts different methods for the satisfaction of the same fundamental human needs. In every system they are satisfied (or not satisfied) through the generation (or non-generation) of different types of satisfiers. We may go as far as to say that one of the aspects that define a culture is its choice of satisfiers. Whether a person belongs to a consumerist or an ascetic society, their fundamental human needs are the same. What changes or what is different, is the person's choice of the quantity and quality of satisfiers (Max-Neef 1992, 200). In short, what are culturally determined are not the fundamental human needs, but the satisfiers for those needs.

Both theories direct attention to the fact that we need to be mindful and appreciative of the vulnerability of marginalised and poverty stricken communities. In order for people to be able to satisfy their needs and living balanced and healthy lives, the concept of development and empowerment is used in this article to include educational development, economic development, social development, and political development (De Coning 2013).

\section{Data and methods}

The study was designed around three phases. Phase one was devoted to a four-week spiritual empowerment programme which the group attended from mid-March to midApril 2013. The programme was facilitated by a pastor from one of the local churches in Gugulethu and the group met at the community hall in Gugulethu, where they also received a daily free meal. It was important for the group to attend this programme because it afforded them the opportunity to voice their feelings, emotions, and concerns about their circumstances, and how that impacted on their self-worth and selfconfidence levels. It also assisted the group to get to know each other, and support and motivate each other as they listened to their different stories and experiences. The facilitator used the sessions to work through all the issues and concerns raised and shared, and provided the group with spiritual guidance and motivational strategies to change their negative self-talk and hopelessness to positive self-talk and empowerment.

Phase two was the period in which the first dataset was collected, which happened in May and June 2013. A comprehensive questionnaire was designed consisting of four sections: a demographic, health information, nutritional, and schooling history section. The questionnaire was manually administrated to the group as they came to the soup kitchen in the community hall. Questions in the demographic section elicited answers that revealed the age, gender, and marital status of participants; whether they had children, lived alone, or with their families and extended families; and whether they had proper shelter, and what they did to survive in terms of an income to provide for their families. The health section covered questions pertaining to their health status, their access to health care services, and whether or not they participated in any type of sport or form of exercise. The questions in the nutritional section focused on their eating patterns and

\section{http://repository.uwc.ac.za}


type of food they ate daily. Lastly, the school history section elicited answers pertaining to whether or not they attended and completed primary school, high school, and any further educational opportunities they might have had.

Mentoring and practical skills training was offered to the group in phase three, the last phase of the study, from August to November 2013. The training was offered separately as it focused on specific skills which the group identified in their sessions with the pastor during the spiritual empowerment programme. The male participants requested practical skills training on carpentry, building, and plumbing, and the female participants preferred training on sewing, baking, and how to start their own small businesses. As a result, the practical skills training sessions focused on building which included carpentry and plumbing for the male participants. These sessions were also offered by the pastor who provided the spiritual empowerment programme because he was a builder by profession, with his own building company.

The training for the females was two-fold. First, because the females wanted to be empowered with knowledge on how to start their own small businesses in order to become self-employed, they attended a three-and-half month educational course on business communication and how to start one's own small business. The course was offered at the university setting. Second, they received practical skills training in constructing "wonder boxes" which are environmentally friendly, energy-saving cooking boxes. The practical skills training courses were offered by a facilitator of the organisation Women for Peace.

The males' practical training sessions took place at different building sites in Gugulethu, whereas the practical training sessions for the females took place at the community hall in Gugulethu. The educational course sessions took place on the campus of the University of the Western Cape. They attended the educational course in two-hour sessions, twice a week, and their practical training sessions on alternative days at the community hall.

The content of the business communication component of the educational course focused on critical thinking and solving problems, effective listening and writing skills, and presentation skills; while the content under starting one's own business focused on how to write a business plan, the components of a business plan, and how to market oneself. The women completed formative assessment tasks for each section, and received a certificate of attendance. They wrote a reflective written piece at the end of the course, and their responses were included as the second dataset of the study.

The collected data consisted of two sets - the comprehensive questionnaire which the whole group completed, and the reflective written piece which the female participants completed. All the responses in the questionnaire were captured on an Excel sheet under the four sections (demographic, health information, nutritional, and schooling history), and cross-checked by both authors to ensure that all the responses were correctly entered. Thereafter, the Excel sheet was sent to the Information System Department where the data were synchronised into Table 1. 


\begin{tabular}{|c|c|c|c|}
\hline Income & & Percentage of participants & \\
\hline $0-R 100$ per month & & $14.8 \%$ & \\
\hline R100-R500 per month & & $37 \%$ & \\
\hline R500-R800 per month & & $33.3 \%$ & \\
\hline R800-R1,000 per month & & $11 \%$ & \\
\hline R1000 - R1600 per month & & $3.7 \%$ & \\
\hline Housing & & Percentage of participants & \\
\hline Living in a house & & $85.1 \%$ & \\
\hline Living in someone's backyard & & $14.8 \%$ & \\
\hline Living in an informal dwelling & & $0 \%$ & \\
\hline Schooling completed & Females & & Males \\
\hline Grade 12 & $11 \%$ & & \\
\hline Grade 9 & $7.4 \%$ & & \\
\hline Grade 8 & & & $74 \%$ \\
\hline Grade 4 & $7.4 \%$ & & \\
\hline Unemployment and health & & Percentage of participants & \\
\hline Unemployed & & $100 \%$ & \\
\hline No medical aid or health insurance & & $100 \%$ & \\
\hline Porridge, fatty foods, and fries & & $100 \%$ & \\
\hline Most pressing needs & & Percentage of participants & \\
\hline 1. Finding employment & & $100 \%$ & \\
\hline 2. To be healthy & & $100 \%$ & \\
\hline 3. To have quality health care services & & $100 \%$ & \\
\hline
\end{tabular}

The table reflects the range of income per month, which is obtained from social grants (80\%) and self-employment (20\%); the kind of housing (85.1\% live in a house and $14.8 \%$ in someone's backyard); their level of schooling completed, with only three females who completed Grade 12, and two who completed Grade 4 only. The male participants all completed Grade 8. Thus, no one continued to higher education. It further shows that, because they were not formally employed, they did not have a medical aid or health insurance, and their basic diet consisted of porridge, fatty foods, and fries which were the most affordable food items. Lastly, all of them identified three most pressing needs, employment, health, and quality health care services.

The responses in the written reflective piece were qualitative in nature and were analysed through an open-coding process (Henning 2004). The first reading of the written reflections ensured an overall sense of what the female participants answered. A second reading allowed for the identification of similar and different responses which were typed and grouped in a Word document. A final reading was done to identify themes, after which the responses were categorised under the themes identified and typed in another Word document. Thus, the open-coding process was inductive because the researchers did not have prior knowledge on how the participants would respond (Henning 2004; Yin 2009). Cross-checking with the original written pieces took place in order to verify the results. In the end, three themes were identified: they learnt how to apply critical thinking and problem solving techniques; attending the course improved their oral and written communication skills; and they gained valuable insights in the sessions on how to start their own small businesses. The results are presented in Figure 1. 


\section{Findings}

The discussion of the findings is structured around the three sub-questions posed in the introductory section in order to find answers to the main question: how could this group of unemployed residents of Gugulethu become empowered and self-reliant?

\section{Female written reflection}

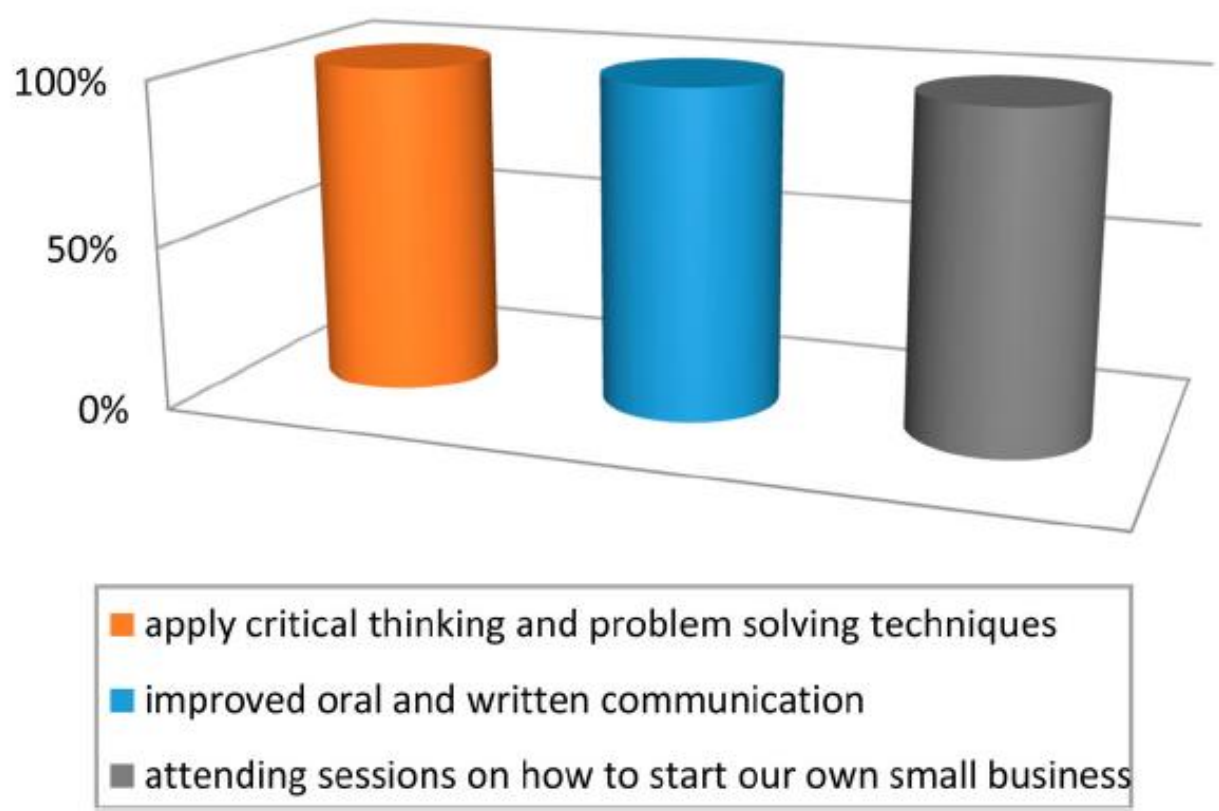

Figure 1. Summary of findings in written reflection piece.

\section{Sub-question 1: what were the most pressing needs of the group?}

Table 1 showed that the group identified three most pressing needs in the questionnaire, namely: finding employment, to be healthy, and to have quality health care services. Finding employment was the most pressing need identified by the entire group. Therefore, the fact that the group members were unemployed was their biggest concern, which as they reported, diminished their dignity, self-respect, and respect from others. They wanted to educate themselves in order to acquire skills so that they can become more employable, and some wanted to start their own small businesses. Their desire to be educated is in line with what Mandela (1994) advocates: "Education is the great engine of personal development."

One could infer from their desire to educate themselves that they realised that they should be the drivers of their own destiny in order to create a better future for their families. In this regard, this factor should be acknowledged because they could have blamed apartheid, felt self-pity, or engaged in criminal activities to satisfy some of their needs, but they did not (Ministry of Finance 2001; Leibbrandt et al. 2009; Organization for Economic Co-operation and Development 2008). Instead, they chose viable alternatives that could assist them to achieve their goals and dreams.

A second important need that they identified was to be healthy. They did not have healthy nutrition, due to a lack of income which resulted in them having various health issues ranging from diabetes, heart problems, and obesity. Their responses show that all 
of them ate bread and mealies as staple food, their favourite foods were a low nutritional porridge, fatty foods and chips, resulting in some of them being overweight. Also, the fact that they did not partake in any form of exercise could be another reason why they were not healthy. The majority (26) indicated that they did not exercise regularly as they were demotivated and apathetic.

As far as their health was concerned, they were dependent on the free services offered by public clinics and hospitals. These services, however, could not provide them with quality health care due to the huge demand but limited resources that the government could provide. Thus, a third most essential need identified was to have quality health care. However, quality health care services were not an option for them because they were unemployed and did not belong to a medical aid scheme, nor did they have the finances to pay for private doctors or hospitals.

\section{Sub-question 2: how could their needs be met and the challenges be overcome?}

The group indicated that all their needs could be met through the provision of employment. Employment meant that they would have a regular income that would enable them to afford proper shelter, provide for their families, purchase healthy food, and belong to medical-aid schemes that would cater for their health needs. However, finding employment was not easy as they did not have a good education, nor were they qualified in a specific trade. As a consequence, some of them indicated that they had already been unemployed for three years or longer. Finding employment, thus, meant that they needed to become educated or skilled in one or another trade in order to create their own employment opportunities. For this reason, we provided them with mentoring and practical skills training sessions from August to November 2013. In addition, it was clear from their responses in the questionnaire that they viewed education and training as the vehicles through which they could achieve their objective of finding employment. This inference was made due to responses such as:

"People who are educated have good jobs."

"I need to have a trade in order to find employment."

"I was told that I do not qualify to work as a cashier because I did not complete my secondary schooling."

Finding employment or becoming self-sustained would also assist them to overcome their challenges. As they were unskilled and unemployed, they could not provide for the needs of their families and extended families. For example, the two females who only completed Grade 4 schooling could not assist their own children with their school work as they themselves were not literate enough to comprehend the content of the subjects of their children. Similarly, because all of them were unemployed, they could not enrol their children in a better quality school. Their children had to attend the quintiles 1 and 2 schooling categories, which meant that it was a no-fee school (African National Congress 2014). Consequently, the children attending these schools do not pay school fees and receive one free meal per day, subsidised by the education department (Republic of 
South Africa 2014, 48). However, these schools are characterised as schools with limited resources, insufficient and unqualified teachers, and large classes (Mdepa and Tshiwula 2012). Therefore, being unskilled and unemployed had a ripple effect of challenges for the group and their families, and the community at large. The group was aware of these challenges which are reflected in their desire to become skilled, trained, and educated.

\section{Sub-question 3: what was the educational value that the women gained from attending the business skills course?}

Three themes were identified as most valuable from the females' responses in the written reflections: learning about critical thinking and solving problems; improving their oral and written communication skills; and gaining valuable insights on how to start their own small businesses. Examples for the first theme on critical thinking and solving problems were:

"I experienced so much and learned things I actually didn't know would come in handy in everyday life, for example, critical thinking skill. I seem to apply that to my everyday thinking now and put in more effect [sic] in problem solving."

"It [the course] also taught me how to be a critical thinker in terms of business, like how I must look at my competitors, what are their strengths and weaknesses and what are mine too!"

The second aspect that all of them commented on was that the course helped them to improve their oral and written communication skills. Examples were:

"The course helped me to improve my speaking and writing in English."

"I have a better understanding of how to construct good sentences."

"Attending the course boasted my confidence to communicate in English."

The improvement of their writing skills over the course of the three months became evident when their first piece of writing was compared with their reflections at the end of the three months.

The last aspect that all of them commented on was how much they have learnt and gained from the second part of the course - how to start my own business, how to write a business plan, and how to market myself. The responses included:

"I also learnt how to draw up a business plan when wanting to start my own business, and very important, that it should be a sustainable business or product that will play a vital role within the community."

"I hope to open my own business. I hope to follow everything I've learned in this course and turn the theory into something practical and see it materialised into a business that 
will bring in money so that I can also create jobs for others and hopefully put my skills training into a venture that will benefit me and everyone in my community."

These reflections indicated that the women not only learnt and gained new knowledge from the course, but it also assisted in improving their self-confidence and self-worth. A final remark in the reflections was that, due to attending the course and gaining new knowledge, they felt that they would want to continue to study and complete a degree. One woman indicated that she was so inspired that she not only wanted to complete a first degree, but continue with postgraduate studies in order to complete her doctorate. Education is indeed the vehicle that can transform people's lives progressively (Mandela 1994; World Bank 2013).

\section{Discussion}

The findings reflect that the groups' basic needs were not being met, which is in direct contradiction to what Max-Neef advocates. Under apartheid, many African and coloured people could not attend high school even if they wanted to because education was provided separately according to racial classification. In many towns, there were no high schools for African and coloured communities (Kros 2010). That is the reason why the male participants only progressed to Grade 8 (Table 1). In addition, because most families were poor, older children had to leave school in order to find some form of employment to assist their parents with the younger ones. They would normally find work as domestic workers in White families' homes, that is why two of the female participants only completed Grade 4 (anonymous personal communication, 12 August 2013). Therefore, as a consequence of apartheid, the group could not access higher education in order to obtain a qualification that could have assisted them to find decent employment and provide in their needs (South African Institute of Race Relations 2015).

As the findings illustrate, the state of unemployment and poverty had a devastating effect on the psychological and emotional well-being of the group, among other effects. They needed some form of "healing" and spiritual enrichment and that was why we deemed it necessary to provide the spiritual empowerment programme which was phase one of the study. The effects of unemployment and poverty are well documented and extend over a wide range of consequences for people in that situation (De Witte, Rothmann, and Jackson 2012). We therefore recommend that counselling and therapeutic services be offered free of charge to unemployed people on a regular basis so that they can speak to professionals and be assisted to work through their feelings of frustration, despair, and hopelessness. We further recommend that future research, especially longitudinal studies, be conducted into psycho-social and spiritual experiences of unemployed community members to gain an in-depth understanding of the effects, in order to find solutions on how best to assist communities to overcome these challenges.

Furthermore, the participants' experiences and unmet needs not only reflected the reality of a large number of Gugulethu residents in the twenty-first century, but also of many other Black communities in South Africa (ibid.). As discussed in the introduction, the challenges and unmet needs that the group had to deal with were to a large extent a direct consequence of the previous government's apartheid ideology and governance. By 
applying capitalism, apartheid left a legacy of income inequality along racial lines for the majority of the Black population (Vygotsky 1979). It is this reality that the present government as well as businesses, private, and public organisations are trying to rectify and improve. The government has attempted to do so through the provision of the Reconstruction and Development Program (RDP) which focused on the construction of low- cost housing in the Black communities; the creation of the Sector Further Education and Training (SETA) which offers skills development programmes to school-leaving children, bridging programmes to learners who did not pass Grade 12 well, and learners programmes and lifelong learning training for adults (Achiever Magazine 2015).

However, the challenge is that many communities do not know how they can access these opportunities and in some cases, they are not aware of them. Thus, we recommend that the Department of Basic Education work more closely with businesses, private organisations, NGOs, community libraries, and schools on awareness campaigns, road shows, and other awareness activities so that more com- munity members will become informed about the training and educational opportunities which are available.

Moreover, the group's experiences and challenges identified clearly reflected the analytical stance of this study - that human development and well-being are socially constructed and that human beings have needs that are universal (Vygotsky 1979, 1994; Max-Neef 1989, 1992). The social situatedness of human beings' development is, first of all, illustrated by the fact that, when people are unemployed, they cannot provide for their basic needs which mean that they cannot satisfy their needs (Max Neef 1989, 1992). When this happens, they become financially needy and, as a consequence, a liability to the state. A high unemployment rate, in turn, is not conducive to the economic growth of a country (Liebenberg 2014; Statistics South Africa 2015).

Second, when people are unemployed some are prone to indulge in criminal activities for survival. The high crime rate and incidents of burglaries, drug abuse, and murders in South Africa could thus be partly also symptoms of the challenges, including unemployment, that are indirect consequences of the previous apartheid's ideology in South Africa (City of Cape Town 2013). The apartheid's governance violated the participants' basic human needs because it did not provide them with opportunities to satisfy their needs. Instead, according to Vygotsky (1979, 1994), it enhanced the application of capitalism and the division of human beings according to race, status, economic, social, and political power. These are reasons why the consequences of apartheid are still felt and experienced by a large portion of the African and coloured Black communities in South Africa today (Liebenberg 2014; Moodley 1995; Tight 2003). Consequently, we recommend that the government together with businesses, private organisations (national and international) and NGOs create more jobs and employment opportunities so that the unemployment rate can be reduced and communities be empowered to rise from poverty.

Third, when people are unskilled and unemployed, it limits and reduces the economic growth of a country and impacts the GDP negatively because there is less buying power. It also places more pressure on the employed people because it means that they 
must compensate for the unemployed with regard to tax revenue for the state. Economists use education, employment, and health factors to determine the HDI (Human Development Index) (Todaro and Smith 2011). In order to be employed and earn an income, one needs to be skilled and educated. When one has an income one can afford good healthcare in order to remain healthy; one can eat properly, and be sanitised and clean. These are all factors which contribute to ones' overall well-being and prosperity as a human being. These factors constitute human development and growth. As Max-Neef argues, when these factors are in place, human beings will be able to satisfy their needs (Max-Neef 1989, 1992). We therefore recommend that the government and big businesses should invest more funds and resources in public schools and community development programmes in order to provide quality education to the general public, and ongoing practical training and skills development opportunities to unemployed community members so that they could become skilled and employable.

In addition, private organisations and NGOs should form partnerships with community organisations, schools, and other educational bodies in order to reach more people and provide training, educational courses, and other recreational activities aimed at uplifting and empowering unemployed communities so that they will become self-reliant.

Finally, we recommend that schools and community organisations should be encouraged to invest in entrepreneurial skills programmes as well as in food gardens and recycling programmes. These gardens will provide vegetables to the communities which will improve their health and in so doing, limit the need to make use of the public health services. Both the food gardens and the recycling programmes will also generate income for schools and communities. The government, big businesses, and private organisations could also create opportunities were unemployed community members be trained and subsidised so that they can start their own small businesses and in that way, become self-sustained. These small businesses could, in turn, create further employment opportunities which will reduce the unemployment rate and enable more people to satisfy their needs.

\section{Concluding remarks}

The issues discussed in this article focused on the needs, challenges, and aspirations of a group of unemployed Black community members living in Gugulethu, one of the Black townships on the Cape Flats in South Africa. The findings demonstrated the daily reality for a group of 27 men and women. What they experienced and report on can be generalised to most of the Black townships in the country due to the legacy of apartheid. However, the issues also speak of hope and human determination in order to overcome adversity as the group were able to identify their needs, requested assistance, and became empowered.

The reality is that the consequences of apartheid in South Africa will still be felt for a long time to come. What is most important is how we deal with and assist poverty stricken communities and unemployed people to overcome their challenges and realise their aspirations, goals, and dreams. In this article, we attempted to find solutions that 
could contribute to the upliftment and empowerment of these communities in South Africa.

\section{Disclosure statement}

No potential conflict of interest was reported by the authors.

\section{Notes on contributors}

Venicia McGhie is an academic developer in the Faculty of Economic and Management Sciences at the University of the Western Cape, South Africa. Her background is education and linguistics. She is a Fulbright Scholar who has been con- ducting research on successful student learning and retention, as well as community development and access to higher education.

Marion Keim is Associate Professor and Director of the Interdisciplinary Centre for Sport Science and Development (ICESSD), University of the Western Cape, South Africa. Her background is sports science, social science and law. Marion has been conducting research, teaching, and community outreach for 25 years in Africa, Europa, the US, and the Caribbean. 


\section{References}

Achiever Magazine. 2015, October. "Formula for Success." Achiever Magazine 52: 28-29.

African National Congress. 2014. "Together We Move South Africa Forward: 2014 Election Manifesto, a Better Life For All.” Accessed February 10, 2014. www.anc.org.za/2014/wp-content/uploads/2014/o1/ANC-Manifesto-Booklet.pdf.

City of Cape Town. 2013. "Census 2011: Suburb Phillipi." Compiled by Strategic Development Information and GIS Department (SDI\&GIS), City of Cape Town. Accessed August 20, 2013. www.capetown.gov.za/en/stats/2011CensusSuburbs/2011_Census_CT_Suburb_P hilippi_Profile.pdf.

Cruz, I., A. Stahel, and M. Max-Neef. 2009. "Towards a Systemic Development Approach: Building on the Human-Scale Development Paradigm.” Ecological Economics 68: 2021-2030.

De Coning, C. 2013. The Case for Sport II: Socio-economic Benefits of Sport and Recreation in the Western Cape. Cape Town: Department of Cultural Affairs and Sport (DCAS) and ICESSD, University of the Western Cape.

De Witte, H., S. Rothmann, and L. T. B. Jackson. 2012. "The Psychological Consequences of Unemployment in South Africa." South African Journal of Economics and Management Sciences 15 (3): 235-252.

Department of Trade and Industry. 2015. Department of Trade and Industry on its 2015 Strategic and Annual Plan. Accessed December 15, 2015. www.dti.gov.za/.

Henning, E. 2004. Finding your way in qualitative research. Pretoria: Van Schaik Publishers.

Kros, C. 2010. The seeds of separate development: Origins of Bantu education. South Africa: UNISA.

Liebenberg, S. 2014. "The potential of the International Covenant on Economic, Social and Cultural Rights as a tool for poverty reduction in South Africa." ESR Review 15 (1): 3-6.

Leibbrandt, M., I. Woolard, H. McEwen, and C. Koep. 2009. "Employment and Inequality Outcomes in South Africa: What Role For Labour Market And Social Policies?” Unpublished report for the OECD, Southern Africa Labour and Development Research Unit, Cape Town: University of Cape Town.

Mandela, N. 1994. Long Walk to Freedom. London: Little Brown.

Max-Neef, M. 1989. "Human Scale Development: An Option for the Future, Development Dialogue.” Journal of International Development Cooperation 1: 780 .

Max-Neef, M. 1992. "Development and Human Needs." In Real- Life EconomicsUnderstanding Wealth Creation, edited by P. Ekind and M. Max-Neef, 197-214. London: Routledge.

Mdepa, W. and L. Tshiwula. 2012. "Student Diversity in South African Higher Education." Widening Participation and Lifelong Learning 13 (1): 19-33. Ministry of Finance. 2001. "National Treasury Report: Republic of South Africa." Accessed February 28, 2015. www. treasury.gov.za/nt/info.aspx.

Moodley, R. 1995. Education for transformation: Black access to higher education. (ed). Leeds: Thomas Danby Publications. 
Organisation for Economic Co-operation and Development. 2008. "Review of National Policies for Education: South Africa." Accessed August 15, 2014. www.oecd.org/publishing/corrigenda.

Porter, M., S. Stern, and M. Green. 2015. "Social Progress Index 2015." Accessed May 1, 2015. www. socialprogressimperative.org/social-progressindexes.

Republic of South Africa. 2014. 20 Year Review South Africa. Pretoria: The Presidency. Statistics South Africa. 2015. Statistical release. P0302. Mid-year population estimates. Accessed May 25, 2016. www.statssa.gov.za/publications/Po302/Po3022015.pdf

South African Institute of Race Relations. 2015. Fast facts. Accessed May 2, 2016. www.irr.org.za/reports-and-publications/ fast-facts/fast-facts-2015

Tight, M. 2003. International perspectives on higher education: Access and exclusion, (2). (ed). United Kingdom: University of Warwick.

Todaro, M. P., and S. C. Smith. 2011. Economic Development. 11th ed. London: Pearson Education.

Vygotsky, L. S. 1979. "Interaction between Learning And Development." In Mind in Society. The Development of Higher Psychological Processes. L.S. Vygotsky, edited by M. Cole, V. John-Steiner, S. Scribner, and E. Souberman, 79-91. London: Harvard University Press.

Vygotsky, L. 1994. “The Socialist Alteration of Man.” In The Vygotsky Reader, edited by R. Van der Veer and J. Valsiner, 175-184. Oxford: Basil Blackwell.

World Bank 2013. Annual Report 2013. Accessed November 2, 2013. www.worldbank.org.

Yin, R. K. 2009. Case Study Research. Designs and Methods. California: Sage. 